\title{
Analysis on the Mode and Competitive Strategy of Electricity Sales in the Background of Electric Power System Reform
}

\author{
Wenyu Zhou \\ Institute of Quantitative \& Technical Economics, Chinese Academy of Social Sciences, Beijing, China \\ Email: zhouwyu@qq.com
}

How to cite this paper: Zhou, W.Y. (2017) Analysis on the Mode and Competitive Strategy of Electricity Sales in the Background of Electric Power System Reform. Energy and Power Engineering, 9, 401-407. https://doi.org/10.4236/epe.2017.94B045

Received: February 20, 2017

Accepted: March 30, 2017

Published: April 6, 2017

\begin{abstract}
A new round of reform of the power system conforms to the national development of the energy revolution and the reform of the electricity market system. As an important promoter of the energy revolution and power reform, a new round of power system reform has brought profound changes to the energy industry and the power industry and the electricity market system has changed dramatically. With the release of the electricity market, market competition intensified. This paper analyzes the competition strategy of electricity sales market, analyzes the characteristics of market participants such as power generation enterprises, power grid enterprises, electricity sales companies and users, and puts forward the corresponding coping strategies to help the market participants to deal with the opportunities and challenges brought by power system reform, provide guidance and reference for the market participants.
\end{abstract}

\section{Keywords}

Electric Selling Market, Competitive Strategy, Electric Power Reform

\section{Introduction}

The CPC Central Committee and the State Council issued "Several Opinions on Further Deepening the Reform of Electric Power System" in March 2015, marking a new round of reform of the electricity market. It clearly expounded the status quo of China's power system and the urgent need to solve through the reform of the problem, accurately grasp the power system reform in the market subject of the powers and responsibilities, clearly pointed out that the direction and measures to deepen the reform, the focus is to build "Open, orderly, competitive, complete" power market system. And specifically issued on the promo- 
tion of the implementation of the implementation of the views of the implementation of electricity, sales side of the market liberalization as one of the key tasks [1].

"Several Opinions on Further Deepening the Reform of Electric Power System" and its supporting documents expressed the central request to steadily push the electricity side of the reform, multi-way to cultivate market subject. The main ways include: the profit model of the grid will be changed from the profit model of the purchase and selling difference income to the profit model of the net fee charged according to the government's designated transmission and distribution price. The establishment of a relatively independent electric power trading institution to form a fair and standardized electricity market platform, And the introduction of competition in the electricity sales side; to restore the power of goods attributes, to achieve efficient allocation of resources, safe, clean and reliable to meet the needs of social electricity to promote the formation of more buy and sell new market.

The main body of the electricity market includes power generation enterprises, power grid enterprises, electricity sales companies and users. Power generation enterprises in the face of diversified business types, multi-form of the market structure and diversified emerging technologies, need to change their positioning, change business role, build integrated energy service platform to provide power supply, energy and energy saving and other forms of service, Grid companies face a wide range of competitive main body, the new power supply system and diversified energy demand, the effective integration of the Internet and power grid, the development of demand side management technology, to provide users with integrated energy solutions, sales companies to overcome the cost reduction, shortage of funds and market protection difficulties, the use of Internet innovation service profit model.

\section{Sell Electricity Market Characteristic Analysis Based on the Power System Reform}

\subsection{Power Grid Enterprise Highlights the Public Service Function}

Along with the advancement of energy revolution and reform of electric power, power grid companies need to ensure people's basic power supply reliability and power quality, and gradually raise the level of business; In the face of economic new normal, all levels governments have offered to attach importance to solve the problem of the people's livelihood, guarantee and improve rural or mountainous area power supply reliability and improving power quality. By energy revolution, the influence of the green revolution, the new energy power generation given ratio increases, the power grid operation requirements further improve, namely on the premise of guarantee the safe and stable operation, given renewable energy, promoting low carbon, environmental protection.

Grid companies change their functions, so as to adapt to the changes in all aspects of the load distribution caused by the adjustments of infrastructure, industrial park, industrial structure. In the face of economic new normal, all levels 
government put forward to increase the infrastructure construction, including industrial park construction and moving changes, public infrastructure construction, which will bring the transfer of load distribution, put forward a new direction for power grid operation management. At the same time, the complex power grid system operation management will gradually become local micro power grid operation management, power grid operation development will face a new object.

\subsection{Electricity Sales Diversified Competition}

With the gradually opening of power sales market, in the future of power sales market, trading main body and market structure will be more wide, all kinds of subjects are likely to discover their own network interfaces, to varying degrees to participate in the energy market, The market players will be increased significantly, types and sell electricity market participation way will also be more diversified.

\subsection{The Diversification and Customization of User Energy Demand}

Users of energy use will develop from a single demand to one-stop integrated energy services, due to the wide access of client distributed energy, energy producers and consumers are likely to occur role conversion, the user can also take part in the sale of electricity market through the distributed energy as an energy supplier, the user's demand for energy tend to be diversified and customized [2].

\section{Orientation Analysis of Electricity Market Subjects}

\subsection{Location of Grid Enterprises in Electricity Market}

Power grid corporation: Electricity spread of online and selling is no longer the main source of income of grid companies [3]. Grid companies will charge the grid-using cost, and provide power-supply services to the power sellers and their users without discrimination. And promise to guarantee power supply business, to ensure the power supply of users have no bargaining power. Power grid enterprises (including the local power company, wholesale county-level power company) continue to sell electricity to users out of market.

Electricity trading center: Its business includes market subject registration, trading, clearing, trading contract summary and electricity trading information. The information of market subject registration, clearing quantity, transaction price and other information real-time synchronization to the grid business, Trading plan information real-time transmission to the power dispatch, to provide electricity trading settlement basis and related services, construction, operation and maintenance of electricity trading technical support system.

Power dispatch center: According to the dispatching process is responsible for the safe operation of the power grid and accident handling, responsible for the power market security and security control of electricity, the implementation of power trading plans and days of real-time transactions and the implementation 
of balanced scheduling.

\subsection{Location of Generation Companies in Power Market}

Power generation enterprises: Business model from the original "single plan" model to the "plan + transaction" to change the power. The business model consists of priority generation and market transaction power, the implementation of priority power generation contracts, according to the rules involved in the electricity market transactions, signed and fulfilled the purchase and sale of electricity contracts.

\subsection{Location of Market Subject in the Power Market}

Power grid company sales company: With independent legal personality, independent operation, and transmission and distribution business, scheduling business, non-market sales of electricity business isolation; in the power transaction structure is not relatively independent, etc., the grid companies owned sales companies temporarily do not carry out competitive sales business;

Sales company with distribution network operation rights: assets with distribution network, fixed business area, a mark measurement, the use of "mark measurement + market sales" business model, placement integration.

Independent sales company: Non-distribution network assets, no fixed business area, engaged in the purchase and sale of electricity business, the use of "household measurement + market sales" business model, virtual operators.

\subsection{Location of Energy Users in Electricity Market}

Market users: Market-oriented retail users, with the option of market subject, free to choose a different power sales to purchase. Market-based direct purchase of users, with market options in accordance with the voltage level or capacity, all the power is involved in market transactions. And could choose purchase all the electricity or part directly from generations and other flexible purchase mode according to their own needs.

Non-marketable users: Limited users, customers without the market users, do not have the right to market, still provided services by the power grid enterprises through a power supply contract.

\section{Analysis of Business Mode of Electricity Market}

\subsection{Electricity Sale Service}

Electricity purchase and sale is the core business of power sales, including power purchase, electricity sales, commissioned power supply and electricity billing business. The electricity purchase business is important to the power market subject, and the market subjects make profits by delivering the electricity they purchase to users. Although the release of the electricity side will bring the diversification of the subjects of power market, but the market-oriented purchase should be happened in the trading center, and purchase will also be subject to 
the rules of the trading center constraints. 2) Customer Focus Analysis

\subsection{Energy Efficiency Services}

Energy efficiency services are designed to reduce energy consumption, optimize energy costs, improve energy supply, discover energy waste, and improve energy efficiency management to achieve sustainable energy savings for enterprise users. In this way, share the benefits through the models like contract energy management.

\subsection{Electricity Service}

The main management model is package of eliminate, fault repair, hosting and other services [4]. Provide operation and maintenance work for power distribution and other energy equipment assets of users, and provide users with a full range of professional all-round personal security services. Services include following projects: 1) Provide routine inspection of high voltage power equipment, power lines, electricity load and so on. 2) Provide the customer high-voltage power equipment (transformers, high-voltage motors, and so on) for a preventive test work each year in strict accordance with the electricity regulations. 3) Provide rapid response to customer power distribution facilities, high-voltage power equipment and power lines fault handling work. 4) In the routine inspection or preventive test arrangements for dust removal and decontamination work. 5) Provide worry-free hosting, outsourcing services for electrical equipment and facilities. 4.3. Social Service

\subsection{Demand Side Response Service}

Through price-based and based on official subsidies or market-based gains. Demand side response service is when the electricity price changes over time or the market is designed when the wholesale market, high price or system reliability is compromised, stimulating demand-side users to reduce incentive-to-use incentives for electricity by market-based price signals, incentives, or direct instructions from system operators. The end user responds to the above situation and changes its short-term power consumption (consumption or consumption level) or long-term power consumption patterns. Demand side response services include demand side response resource mining, demand side response scheme development, demand side response scheme release, demand side response settlement and evaluation. Demand side response resource mining is based on the demand side of the power generation market and the demand side of the response signal, the timely response to the demand side to assess the value of resources and assess the value of timely decision whether to participate in the response. The demand side response scheme is formulated based on the dynamic supply and demand forecasting results of the grid, and the demand side response scheme based on price or incentive. Demand side response program release is through the control platform to dynamically release the demand side response program, including price, load and other information. Demand side response 
settlement and evaluation are based on the number of participants in response to the user to calculate the amount of incentive, and assess the demand side to respond to the implementation of the effect.

\section{Analysis on Market Competitive Strategy of Market Subject}

\subsection{Market Competitive Strategy Based on Internal Cost}

Based on the internal cost of the bidding strategy, through the cost of power generation into the estimated and assessed in accordance with the cost of bidding to recover, it ensure that the power generation company reliable and stable income, in order to facilitate reproduction, access to a larger market share [5].

\subsection{Strategy of Market Competition Strategy Based on Evolutionary Game}

The bidding process is carried out in a space with uncertainty and bounded rationality, by analyzing the competitor's market power and the possible competitive strategy, the evolutionary game model is constructed to analyze the spontaneous formation process of the bidding strategy of the power generation company, and the evolutionary stability strategy of an evolutionary model is obtained by spontaneous evolution.

\subsection{Electricity Combination Trading Strategy}

Based on the theory of hedging, this paper proposes a model to optimize the monthly purchase of electricity sales by "borrowing and recharging". In the province outside the price of electricity is lower than the contract price, the appropriate compression contract power, set aside more space for outsourcing, In the province outside the electricity price is not enough attractive, in order to ensure the annual contract completion rate, the timely increase in the proportion of planned electricity to make up for "by electricity" caused by the implementation of the contract deviation [6]. Based on the "borrowing and recharging" the purchase of electricity optimization, can effectively reduce the abandon of wind and water, improve the economic and social benefits of electricity sales [7].

\section{Concluding Remarks}

With the release of the electricity market, market competition intensified. In order to occupy a favorable position in a diversified market, to provide users with a variety of customized services, to carry out sales services, energy efficiency services, electrical services and other diversified services. Based on the analysis of the competition strategy of the electricity sales market under the reform of the electric power system, this paper introduces the market competition strategy based on the internal cost, the market competition strategy based on the evolutionary game and the electricity trading strategy to provide guidance and reference for the market participants. 


\section{Acknowledgements}

Thanks to financial aid sponsored by Beijing Social Science Fund, as well as guidance and assistance that units and individuals provide during the research work.

\section{Fund}

Beijing Social Science Fund (15JDJGB034).

\section{References}

[1] (2015). Several Opinions on Further Deepening the Reform of Electric Power System. (Zhongfa(2015)No.9). National assembly of the PRC.

[2] Zang, N.N. (2016) How to Set up Marketing System under Electricity System Reform. Energy of China, 4, 44-47.

[3] Wu, Q.M. (2016) Reflections on the Market of Competitive Sale in the Situation of Electric Power System Reform. Modern SOE Research, 8, 31-33.

[4] Xu, Y. (2016) Discussion on the Operation of Electricity Sales Company under the Reform of New Electric Power System. Light Industry Science and Technology, 3, 130-131.

[5] Huang, K.R. (2016) Research on Competitive Strategy of Sales Main Body under the Background of Electric Power System Reform. North China Electric Power University.

[6] Sun, Q. (2005) Research on the Reform of Electricity Market in China Based on the Construction of Competitive Electricity Sales Market. Hunan University.

[7] Zhang, X.H., Xue, S., Yang, S., Tu, J.M. and Ma, L. (2016) Market Experience of Electricity Market and Its Enlightenment. Automation of Electric Power Systems, 9, $1-8$.

\section{Scientific Research Publishing}

Submit or recommend next manuscript to SCIRP and we will provide best service for you:

Accepting pre-submission inquiries through Email, Facebook, LinkedIn, Twitter, etc. A wide selection of journals (inclusive of 9 subjects, more than 200 journals) Providing 24-hour high-quality service

User-friendly online submission system

Fair and swift peer-review system

Efficient typesetting and proofreading procedure

Display of the result of downloads and visits, as well as the number of cited articles Maximum dissemination of your research work

Submit your manuscript at: http://papersubmission.scirp.org/

Or contact epe@scirp.org 